\title{
Efficacy of Profilactic and Therapeutic Antibiotic in Congenital Hydrocephalus Shunt Infection
}

\author{
Akhmad Imron, Kahdar Wiriadisastra \\ Department of Neurosurgery, Faculty of Medicine Padjadjaran University/ \\ Hasan Sadikin Hospital Bandung \\ Jl. Pasteur No. 38 Bandung 40161 Indonesia \\ Email:aimbd@yahoo.com
}

\begin{abstract}
Prophylactic dose antibiotic are indicated in patients having neurosurgical clean operations with implant surgery. The aim of this study is to evaluate the efficacy of prophylactic dose antibiotic in shunt infection. Between 1 October 2009 until 31 September 2011, 102 patients with congenital hydrocephalus who underwent VP shunt surgery. Fifty-one received profilactic antibiotic (ceftriaxone 50-75 $\mathrm{mg} / \mathrm{kgBW}$ ), 30-60 minutes before surgery until 5 days post-operative, and 51 patients received therapeutic antibiotic (ceftriaxone 50-75 $\mathrm{mg} / \mathrm{kgBW}$ ), 30-60 minutes before surgery until 1 days post-operative. All patient were followed for 1-6 months to evaluate shunt infection. Collected data will be statistically analyzed. The study found that the rate of infection is $17,6 \%$ (9 patients of 51 patients) who received therapeutic antibiotic, and 17,6\% (9 patients of 51 patients) who received profilactic antibiotic.There is not statistically significant between all group in shunt infection $(p=1,000)$. Others risk factors significantly influence shunt infection are enlargement of the head $(p=0,002)$, length of surgery $(p=0,00327)$, time of surgery $(p=0,00077)$ and nutrition status $(p=0,01343)$. The results of this study indicate that profilactic antibiotic effective to prevent shunt infection in congenital hydrocephalus. Others risk factors significantly influence are enlargement of the head, length of surgery, time of surgery and nutrition status.
\end{abstract}

Keywords: antibiotic, prophylactic, infection, VP shunt, congenital hydrocephalus 


\title{
Efektivitas Pemberian Antibiotik Profilaksis dan Terapeutik dalam Pencegahan Infeksi setelah Tindakan Ventrikuloperitoneal Shunt pada Hidrosefalus Kongenital
}

\author{
Akhmad Imron, Kahdar Wiriadisastra \\ Departemen Bedah Saraf, Fakultas Kedokteran, \\ Universitas Padjadjaran-Rumah Sakit Hasan Sadikin, \\ Jl. Pasteur No. 38 Bandung 40161 Indonesia \\ Email:aimbd@yahoo.com
}

\begin{abstract}
Abstrak
Antibiotik profilaksis diberikan pada tindakan bedah saraf seperti pada tindakan VentrikuloPeritoneal (VP) shunt. Penelitian ini untuk mengetahui pengaruh pemberian antibiotik profilaksis dan terapeutik dalam pencegahan infeksi setelah tindakan VP shunt pada penderita hidrosefalus kongenital. Penelitian dilakukan mulai 1 Oktober 2009 hingga 31 September 2011, jumlah subjek sebanyak 102 penderita hidrosefalus kongenital yang menerima tindakan VP shunt. Sebanyak 51 penderita, mendapat perlakuan A, yaitu diberi antibiotik terapeutik (ceftriaxone $50-75 \mathrm{mg} / \mathrm{kgBB}$ ), 30-60 menit sebelum operasi sampai 5 hari pascaoperasi; 51 penderita mendapat perlakuan $B$, yaitu diberi antibiotik profilaksis (ceftriaxone 50-75 $\mathrm{mg} / \mathrm{kgBB}$ ), 30-60 menit sebelum operasi dan sampai 1 hari pascaoperasi. Kedua kelompok perlakuan di follow-up sampai 1-6 bulan pascaoperasi. Data dianalisis menggunakan uji chikuadrat, uji Kruskal-Wallis, dan analisis regresi logistik ganda. Hasil penelitian adalah kejadian infeksi pada perlakuan A sebanyak 17,6\% ; pada kelompok B sebanyak 17,6\%. Tidak didapati perbedaan yang bermakna di antara kedua kelompok perlakuan terhadap kejadian infeksi pascaoperasi $(\mathrm{p}=1,000)$. Terdapat faktor-faktor resiko lain yang sangat bermakna mempengaruhi kejadian infeksi yaitu pembesaran lingkar kepala, lama operasi, waktu operasi dan status gizi. Simpulan, pemberian antibiotik profilaksis sama efektifnya dengan pemberian antibiotik terapeutik pada penderita hidrosefalus kongenital yang dilakukan tindakan VP shunt.
\end{abstract}

Kata kunci: antibiotika, profilaksis, infeksi, VP shunt, hidrosefalus kongenital 
Research Article

\section{Pendahuluan}

Pemberian antibiotik profilaksis pada tindakan bedah saraf sampai saat ini masih merupakan masalah yang kontroversial. Pada tindakan bedah saraf, potensi untuk terjadinya morbiditas dan mortalitas akibat infeksi pascaoperasi sangat tinggi yaitu 35-40\%. Komplikasi operasi berupa meningitis, osteomielitis, atau timbulnya abses akan memperburuk hasil operasi itu sendiri. ${ }^{1,2}$ Penggunaan antibiotik profilaksis pada jenis operasi contaminated wound atau dirty wound sudah terbukti manfaatnya untuk menurunkan angka infeksi pascaoperasi, sedangkan pada jenis operasi clean wound pemberian antibiotik profilaksis masih kontroversial. ${ }^{2-6}$

Efek maksimal antibiotik profilaksis didapat bila cara pemberiannya mengikuti petunjuk tertentu dengan memperhatikan waktu, cara pemberian, dan pemilihan jenis antibiotik yang digunakan. Pemberian antibiotik 2 jam sebelum operasi memberikan hasil yang baik dalam menurunkan infeksi pascaoperasi. Antibiotik profilaksis diberikan sampai lebih dari 24 jam pascaoperasi, tidak dianjurkan pada jenis operasi clean wound dan contaminated wound. . $^{3-6}$

Penelitian mengenai pemberian antibiotik profilaksis pada operasi VentriculoPeritoneal (VP) Shunt memperlihatkan hasil yang signifikan dalam menurunkan angka kejadian infeksi pascaoperasi. Namun dari banyak penelitian tersebut hanya sedikit yang menggunakan metode penelitian prospektif, random, dan double blind. ${ }^{7,8}$

Hidrosefalus kongenital merupakan kelainan kongenital terbanyak (54\%) yang dirawat di bangsal bedah saraf Rumah sakit Hasan Sadikin Bandung, sedangkan meningoencephalocele sebanyak 39\% dan meningomyelocele 7\%. Pada semua penderita dengan hidrosefalus kongenital tersebut dilakukan tindakan diversi, dalam hal ini dilakukan tindakan VP shunt. ${ }^{9}$

Cerebrospinal fluid (CSF) shunting merupakan tindakan bedah saraf yang termasuk jenis operasi clean wound dengan pemasangan implant. Tindakan CSF shunting ini mempunyai risiko tertinggi untuk terjadinya infeksi pascaoperasi. Hasil penelitian 8 tahun terakhir mendapati bahwa kejadian infeksi shunt antara 10-20\%, sedangkan penelitian terakhir menunjukkan angka sekitar 5\%. Penurunan angka kejadian infeksi yang bermakna tersebut berhubungan erat dengan kemajuan teknik operasi, penggunaan antibiotik profilaksis, dan meningkatnya pengalaman para ahli bedah saraf. ${ }^{6-7-12,16-21}$ Menurut data tahun 2003, kejadian infeksi shunt di bangsal bedah saraf RSHS adalah sebesar $17,6 \%$ per tahun. ${ }^{9}$

Sampai saat ini, di bangsal perawatan Bedah Saraf RSHS, untuk penderita pasca VP shunt masih diberikan terapi antibiotik terapeutik (lama pemberian $\geq 5$ hari ). Oleh karena itu peneliti tertarik untuk membandingkan pengaruh pemberian antibiotik profilaksis dan terapeutik 
Research Article

dalam pencegahan infeksi pada hidrosefalus kongenital setelah dilakukan tindakan VentrikuloPeritoneal shunt.

\section{Metode}

Subjek penelitian adalah para penderita hidrosefalus kongenital yang menerima tindakan VP shunt dan dirawat di Bagian/SMF di Bagian/SMF Bedah Saraf RSHS, mulai 1 Oktober 2009 sampai dengan 31 September 2011, yang memenuhi kriteria inklusi dan eksklusi penelitian. Kriteria inklusi yaitu penderita hidrosefalus kongenital usia 0-2 tahun, tidak disertai kelainan kongenital lain, tidak ada tanda-tanda infeksi sistemik. Kriteria eksklusi yaitu penderita dengan panas badan dan peningkatan sel darah putih selama masa rawat. Pengambilan sampel dilakukan secara "consecutive".

Penelitian potong lintang ini dilakukan secara prospektif, variabel bebas yaitu jenis pemberian antibiotik yang digunakan dan variabel terikat yaitu kejadian infeksi setelah tindakan VP shunt.

Semua penderita hidrosefalus kongenital yang dilakukan tindakan VP shunt dan memnuhi kriteria inklusi dan eksklusi penelitian, serta memberikan persetujuan untuk ikut serta dalam penelitian (informed consent) dimasukkan sebagai subjek penelitian. Subjek dibagi menjadi dua kelompok yaitu kelompok perlakuan A mendapat antibiotik terapeutik (ceftriaxone 50-75 mg/kgBB), 30-60 menit preoperasi dan sampai $\geq 5$ hari post VP shunt, sedangkan kelompok perlakuan B mendapat antibiotik profilaksis (ceftriaxone $50-75 \mathrm{mg} / \mathrm{kgBB}$ ), 30-60 menit preoperasi dan sampai 1 hari post VP shunt. Kedua kelompok perlakuan dipantau selama 1-6 bulan untuk mengetahui kejadian infeksi pasca VP shunt. Infeksi yang diteliti pada penelitian ini meliputi infeksi pada luka operasi dan atau ventrikulitis. Diagnosis infeksi ditegakkan dengan pemeriksaan klinis (demam, kemerahan pada luka operasi, adanya pus pada luka operasi, kejang, dll), laboratoris (kadar leukosit $>10.000 / \mathrm{mm}^{3}$, radiologis (CT scan) dan kultur.

Untuk mengetahui perbedaan kejadian infeksi pada kedua kelompok perlakuan digunakan uji chi kuadrat dan uji Kruskal-Wallis. Kemaknaan ditentukan berdasarkan nilai $\mathrm{p}<0,05$. Kemudian dilakukan analisis regresi logistik ganda untuk mengetahui kekuatan seberapa besar hubungan yang ada diantara variabel-variabel yang bermakna, bila memang diantara keduanya terdapat hubungan yang signifikan. Dilakukan uji pearson chi square dalam pengambilan keputusan terhadap hipotesis. 
Research Article

\section{Hasil}

Karakteristik Subjek Penelitian

Pada penelitian ini terdapat 102 penderita hidrosefalus kongenital yang memenuhi kriteria penelitian. Dari 102 penderita tersebut, 51 penderita mendapat perlakuan A (diberi antibiotik sampai 5 hari), terdiri atas 21 laki-laki dan 30 perempuan dengan umur rata-rata 7,255 bulan (SD 6,91), median 6 bulan dan rentang 0-24 bulan; 51 penderita mendapat perlakuan B (diberi antibiotik sampai 1 hari, terdiri atas 28 laki-laki dan 23 perempuan dengan umur rata-rata 7,412 bulan (SD 7,077), median 5 bulan dan rentang 0-24 bulan. Hasil uji chi-kuadrat untuk karakteristik jenis kelamin menunjukkan $\mathrm{p}=0,165$; untuk status gizi $\mathrm{p}=0,836$; untuk waktu operasi $\mathrm{p}=0,682$; untuk lama operasi $\mathrm{p}=0,837$ dan hasil uji Mann-Whitney untuk karakteristik umur $\mathrm{p}=0,792$; untuk penambahan lingkar kepala $\mathrm{p}=0,836$. Hasil-hasil di atas membuktikan bahwa karakteristik subjek penelitian adalah homogen, sehingga dapat dilakukan uji perbandingan di antara kedua kelompok perlakuan tersebut (Tabel 1).

\section{Hubungan antara Variabel-Variabel dengan Kejadian Infeksi}

Terdapat hubungan yang sangat bermakna $(\mathrm{p}<0,01)$ antara penambahan lingkar lepala, waktu operasi dan lamanya operasi dengan kejadian infeksi, serta hubungan yang bermakna $(\mathrm{p}<0,05)$ antara kelompok umur dan status gizi dengan kejadian infeksi. Sementara itu untuk jenis kelamin tidak terdapat hubungan yang bermakna dengan kejadian infeksi $(p>0,05)$ (Tabel 2). 
Tabel 1 Karakteristik Penderita yang Mendapat Pengobatan Antibiotika

\begin{tabular}{|c|c|c|c|c|}
\hline \multirow[b]{2}{*}{ No } & \multirow[b]{2}{*}{ Karakteristik } & \multicolumn{2}{|c|}{ Perlakuan } & \multirow[b]{2}{*}{ Kemaknaan } \\
\hline & & $\begin{array}{c}\mathrm{A} \\
(\mathrm{n}=51)\end{array}$ & $\begin{array}{c}\text { B } \\
(n=51)\end{array}$ & \\
\hline \multirow[t]{8}{*}{1.} & Umur: & & & \\
\hline & $0-6$ & 29 & 33 & \\
\hline & $7-12$ & 14 & 12 & \\
\hline & $13-18$ & 4 & 5 & \\
\hline & $19-24$ & 4 & 1 & \\
\hline & $\mathrm{X}(\mathrm{SD})$ & $7,255(6,910)$ & $7,412(7,077)$ & \\
\hline & Median & 6 & 5 & $\mathrm{Z}_{\mathrm{MW}}=0,262$ \\
\hline & Rentang & $0-24$ & $0-24$ & $\mathrm{p}=0,793$ \\
\hline \multirow[t]{3}{*}{2.} & Jenis Kelamin : & & & \\
\hline & Laki-laki & 21 & 28 & $X^{2}=1,924$ \\
\hline & Perempuan & 30 & 23 & $\mathrm{p}=0,165$ \\
\hline \multirow[t]{7}{*}{3.} & \% Penambahan LK: & & & \\
\hline & $<15 \%$ & 28 & 33 & \\
\hline & $15 \%-<30 \%$ & 18 & 12 & \\
\hline & $\geq 30 \%$ & 5 & 6 & \\
\hline & $\mathrm{X}(\mathrm{SD})$ & $16,847(10,427)$ & $17,4(11,559)$ & \\
\hline & Median & 13,7 & 13,1 & $\mathrm{Z}_{\mathrm{MW}}=0,207$ \\
\hline & Rentang & $2,2-52,8$ & $5,3-61,4$ & $\mathrm{p}=0.836$ \\
\hline \multirow[t]{4}{*}{4.} & Status Gizi: & & & \\
\hline & Kurang & 11 & 10 & \\
\hline & Sedang & 25 & 25 & $X^{2}=0,080$ \\
\hline & Baik & 15 & 16 & $\mathrm{p}=0,961$ \\
\hline \multirow[t]{3}{*}{5.} & Waktu Operasi: & & & \\
\hline & Pertama & 31 & 33 & $X^{2}=0,168$ \\
\hline & Kedua,dst & 20 & 18 & $\mathrm{p}=0,682$ \\
\hline \multirow[t]{3}{*}{6.} & Lama Operasi: & & & \\
\hline & $<1 \mathrm{jam}$ & 33 & 32 & $X^{2}=0,042$ \\
\hline & $>1 \mathrm{jam}$ & 18 & 19 & $\mathrm{p}=0,837$ \\
\hline
\end{tabular}

Keterangan: $\mathrm{SD}=$ Standar Deviasi

$\mathrm{X}^{2}=\mathrm{Uji}$ chi kuadrat

$\mathrm{Z}_{\mathrm{MW}}=\mathrm{Uji}$ Mann-Whitney 
Tabel 2 Hubungan Berbagai Variabel dengan Kejadian Infeksi

\begin{tabular}{|c|c|c|c|c|}
\hline \multirow[b]{2}{*}{ No } & \multirow{2}{*}{ Variabel } & \multicolumn{2}{|c|}{ Kejadian infeksi } & \multirow{2}{*}{ Kemaknaan } \\
\hline & & Infeksi & Tidak infeksi & \\
\hline \multirow[t]{8}{*}{1.} & Umur: & & & \\
\hline & $0-6$ & 7 & 54 & \\
\hline & $7-12$ & 5 & 21 & \\
\hline & $13-18$ & 3 & 2 & \\
\hline & $19-24$ & 3 & 7 & \\
\hline & $\mathrm{X}(\mathrm{SD})$ & $11,056(7,893)$ & $6,536(6,522)$ & \\
\hline & Median & 9,5 & 4 & $\mathrm{Z}_{\mathrm{MW}}=2,411$ \\
\hline & Rentang & $0-24$ & $0-24$ & $\mathrm{p}=0,016$ \\
\hline \multirow[t]{3}{*}{2.} & Jenis kelamin : & & & \\
\hline & Laki-laki & 9 & 40 & $X^{2}=0,033$ \\
\hline & Perempuan & 9 & 44 & $\mathrm{p}=0,855$ \\
\hline \multirow[t]{4}{*}{3.} & Pembesaran lingkar kepala: & & & \\
\hline & $<15 \%$ & 6 & 55 & \\
\hline & $15 \%-<30 \%$ & 8 & 22 & $\mathrm{Z}_{\mathrm{MW}}=3,094$ \\
\hline & $\geq 30 \%$ & 4 & 7 & $\mathrm{p}=0,002$ \\
\hline \multirow[t]{4}{*}{4.} & Status gizi: & & & \\
\hline & Kurang & 8 & 13 & \\
\hline & Sedang & 7 & 43 & $X^{2}=6,11126$ \\
\hline & Baik & 3 & 28 & $\mathrm{p}=0,01343$ \\
\hline \multirow[t]{3}{*}{5.} & Waktu operasi: & & & \\
\hline & Pertama & 5 & 59 & $X^{2}=11,32077$ \\
\hline & Kedua,dst & 13 & 25 & $\mathrm{P}=0,00077$ \\
\hline \multirow[t]{3}{*}{6.} & Lama operasi: & & & \\
\hline & $<1 \mathrm{jam}$ & 6 & 59 & $X^{2}=8,64814$ \\
\hline & $>1 \mathrm{jam}$ & 12 & 25 & $\mathrm{p}=0,00327$ \\
\hline
\end{tabular}

Hubungan antara Penambahan Lingkar Kepala dan Status Gizi dengan Kejadian Infeksi

Hubungan antara penambahan lingkar kepala dengan kejadian infeksi menunjukkan perbedaan yang bermakna (Tabel 2). Kebermaknaan tersebut disajikan pada Gambar 1 dan Gambar 2. 


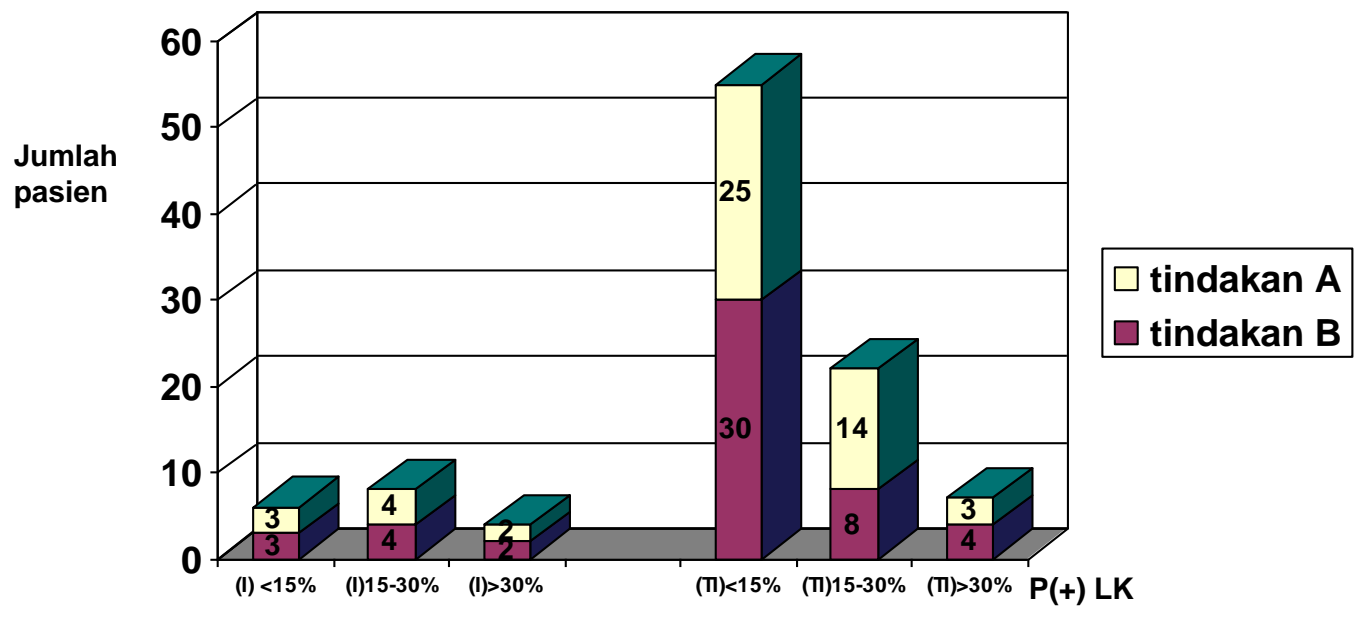

Gambar 1 Hubungan antara Penambahan Lingkar Kepala dengan Kejadian Infeksi berdasarkan Jenis Perlakuan

Keterangan: (I): infeksi, (TI): tidak infeksi, $\mathrm{P}(+)$ LK: penambahan lingkar kepala

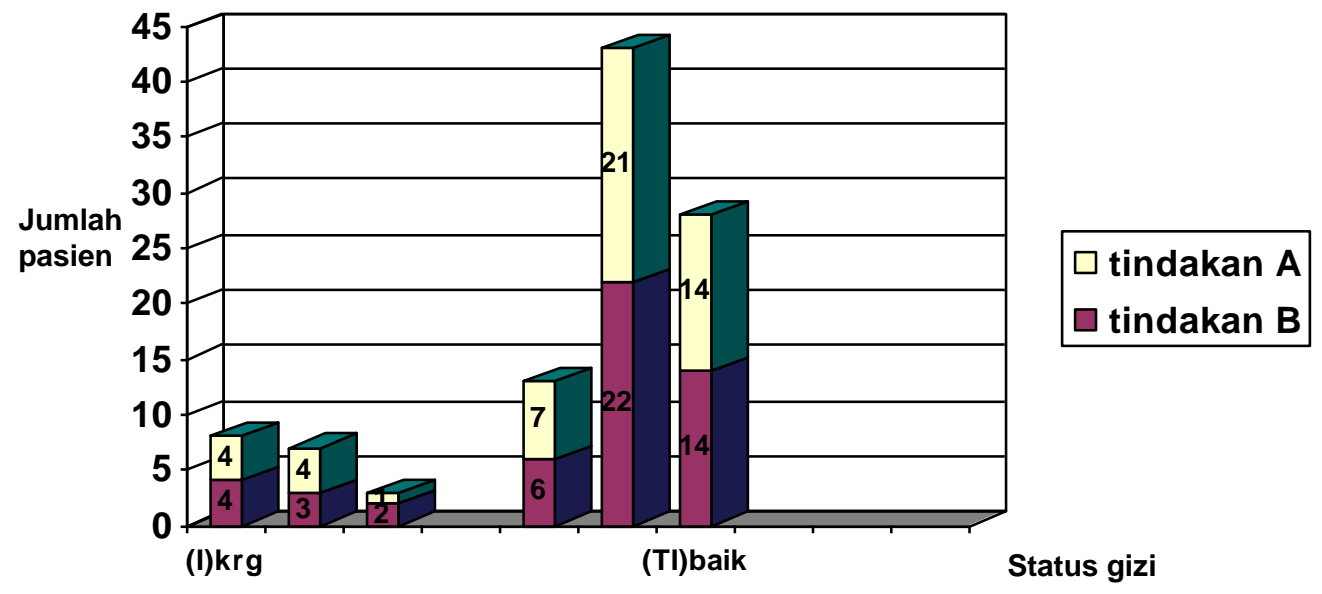

Gambar 2 Hubungan antara Status Gizi dengan Kejadian Infeksi berdasarkan Jenis Perlakuan

Keterangan: (I) krg: infeksi, status gizi kurang

(I) sdg: infeksi, status gizi sedang

(I) baik: infeksi, status gizi baik

(TI) krg: tidak infeksi, status gizi kurang

(TI) sdg: tidak infeksi, status gizi sedang

(TI) baik: tidak infeksi, status gizi baik 
Research Article

Hubungan antara Waktu dan Lamanya Operasi dengan Kejadian Infeksi

Hubungan antara waktu dan lamanya operasi dengan kejadian infeksi menunjukkan perbedaan yang bermakna (Tabel 2). Kebermaknaan tersebut disajikan pada Gambar 3 dan Gambar 4.

Berdasarkan hasil di atas kemudian dilakukan analisis regresi logistik ganda untuk mengetahui kekuatan seberapa besar hubungan yang ada diantara variabel-variabel yang bermakna, bila memang diantara keduanya terdapat hubungan yang signifikan (Tabel 3).

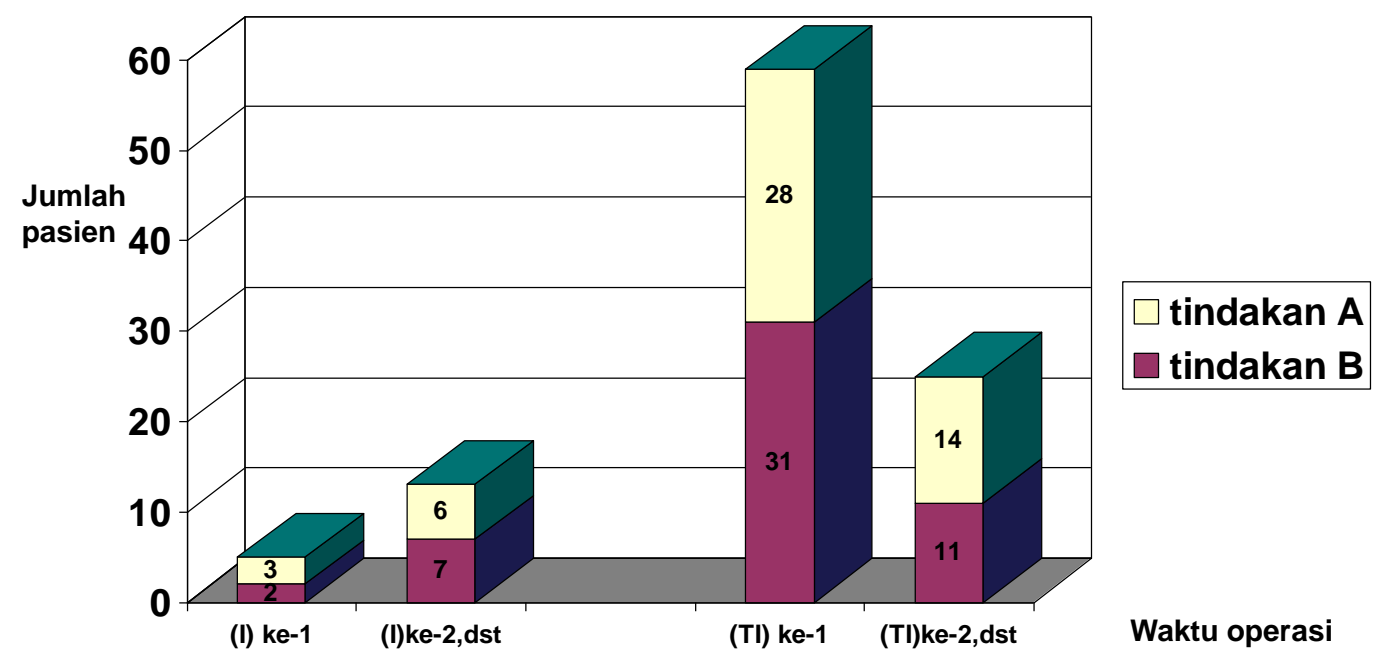

Gambar 3 Hubungan antara Waktu Operasi dengan Kejadian Infeksi berdasarkan Jenis Perlakuan

Keterangan : (I): infeksi, (TI): tidak infeksi 


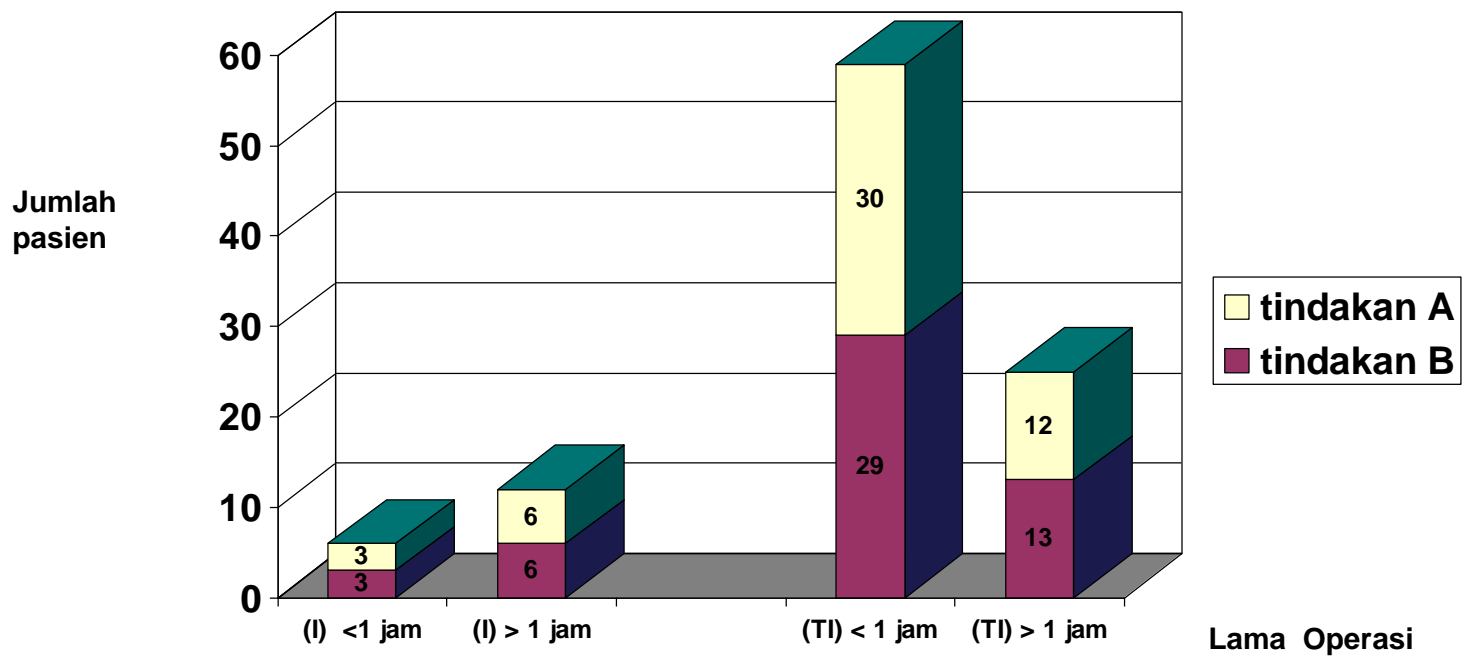

Gambar 4 Hubungan antara lamanya Operasi dengan Kejadian Infeksi berdasarkan Jenis Perlakuan

Keterangan : (I): infeksi, (TI): tidak infeksi

Tabel 3 Analisis Regresi Logistik Ganda Faktor-faktor yang Mempengaruhi Kejadian Infeksi

\begin{tabular}{lllll}
\hline Variabel & Koef. B & SE(B) & Nilai p & OR(95\%CI) \\
\hline Penambahan LK & 1,0102 & 0,4611 & 0,0285 & $2,7463(1,1124-6,7799)$ \\
Waktu Operasi & 1,5695 & 0,6507 & 0,0159 & $4,8044(1,3419-17,2011)$ \\
Lama Operasi & 1,9227 & 0,6740 & 0,0043 & $6,8396(1,8254-25,6274)$ \\
Status Gizi & 0,7179 & 0,4354 & 0,0992 & $0,4878(0,2078-1,1451)$ \\
Perlakuan & 0,0564 & 0,6338 & 0,9291 & $1,0580(0,3055-3,6646)$ \\
Konstanta & $-7,0328$ & & & \\
\hline \multicolumn{2}{l}{ Keterangan: Akurasi : $90,20 \%$, OR=Odds Ratio, CI=Confidence Interval. }
\end{tabular}

Dari analisis regresi logistik ganda didapatkan besarnya peluang infeksi dari berbagai variabel yang mempunyai hubungan yang signifikan dengan kejadian infeksi, peluang infeksi tertinggi $(0,915)$ terdapat pada pasien dengan status gizi kurang, lama operasi $>1$ jam, waktu operasi yang kedua, dan penambahan lingkar kepala $>30 \%$.

Berdasarkan uji chi kuadrat, hubungan antara jenis perlakuan dengan kejadian infeksi (Tabel 4) didapatkan hasil probabilitas $\mathrm{p}=1,000$, dan diketahui bahwa probabilitas di atas 0,05 $(1,000>0,05)$ maka H0 diterima, sehingga diketahui tidak ada hubungan antara kejadian infeksi dengan jenis perlakuan. 
Tabel 4 Hubungan antara Jenis Perlakuan dengan Kejadian Infeksi

\begin{tabular}{lcc}
\hline Kejadian & \multicolumn{2}{c}{ Antibiotika } \\
\cline { 2 - 3 } & $\begin{array}{c}\mathrm{A} \\
(\mathrm{n}=51)\end{array}$ & $\begin{array}{c}\mathrm{B} \\
(\mathrm{n}=51)\end{array}$ \\
\hline Infeksi & $9(17,6)$ & $9(17,6)$ \\
\hline Tidak infeksi & $42(82,4)$ & $42(82,4)$ \\
\hline Keterangan: $\mathrm{X}^{2}=0,000 ; \mathrm{p}=1,000$ &
\end{tabular}

\section{Diskusi}

Pada penelitian ini didapatkan bahwa pemberian antibiotika secara profilaksis cukup efektif untuk mencegah infeksi setelah pemasangan VP shunt pada penderita hidrosefalus kongenital. Hal ini sesuai dengan penelitian sebelumnya yang menyatakan bahwa CSF shunting merupakan tindakan bedah saraf yang termasuk clean surgery dan pada jenis operasi ini, pemberian antibiotika secara profilaksis memberikan hasil yang baik dalam menurunkan kejadian infeksi pascaoperasi. ${ }^{1,2}$

Terdapat faktor-faktor risiko lain yang secara sangat bermakna mempengaruhi kejadian infeksi setelah tindakan VP shunt yaitu pembesaran lingkar kepala, lama operasi, waktu operasi, dan yang bermakna mempengaruhi kejadian infeksi setelah tindakan $V P$ shunt yaitu status gizi, di mana peluang infeksi tertinggi terdapat pada pasien dengan status gizi kurang, lama operasi > 1 jam, waktu operasi yang kedua dan penambahan lingkar kepala $>30 \%$.

Semakin meningkatnya usia penderita maka makin tinggi kejadian infeksi setelah tindakan VP shunt. Hasil ini berbeda dengan peneliti lain yang menyatakan bahwa pasien umur $<1$ tahun menunjukkan angka infeksi yang lebih tinggi dari usia yang lebih tua dan insiden infeksi pasca shunting pada populasi neonatus ( $<1$ bulan) 2 sampai 3 kali lebih banyak dari kelompok usia $>6$ bulan. Para peneliti tersebut menyimpulkan bahwa pada neonatus mempunyai lapisan epidermis yang tipis sehingga fungsi proteksinya kurang, jumlah flora kulit yang resisten lebih banyak, adhesi bakteri lebih tinggi, immunoglobulin kurang dan adanya aktivasi komplemen. ${ }^{11-13}$ Hasil yang berbeda ini diduga disebabkan karena dengan semakin tua umur penderita semakin besar lingkar kepalanya, sehingga ketebalan lapisan epidermisnya makin tipis yang berakibat lebih lanjut terhadap meningkatnya resiko infeksi pasca operasi VP shunt.

Makin besar penambahan lingkar kepala penderita maka makin besar angka kejadian infeksi pasca VP shunt. Hasil ini tidak berbeda dengan penelitian sebelumnya yang menyatakan bahwa makin besarnya lingkar kepala menyebabkan kulit kepala semakin tipis sehingga meningkatkan risiko terjadinya infeksi. Hal ini terjadi karena dengan semakin besarnya penambahan lingkar kepala maka kulit kepala penderita menjadi semakin tipis. Dengan semakin 


\section{Research Article}

tipisnya kulit penderita maka akan berakibat menjadi mudah robek akibat gesekan, sehingga akan mudah terjadinya infeksi. ${ }^{11-12}$

Makin buruk status gizi penderita maka semakin besar risiko terjadinya infeksi paska tindakan VP shunt. Hasil ini sesuai dengan peneliti lain yang menyatakan bahwa makin buruk status gizi penderita menyebabkan menurunnya kondisi kekebalan penderita dan tipisnya lapisan epidermis kulit penderita, sehingga menyebabkan kejadian infeksi pasca VP shunt lebih tinggi. ${ }^{11-}$ 12

Semakin awal operasi dilakukan dan semakin pendek lama operasi maka akan semakin rendah angka kejadian infeksi pasca VP shunt. Hasil ini sesuai dengan penelitian sebelumnya yang menyatakan bahwa dengan teknik aseptik dan antiseptik yang baik, operasi dilakukan pada jam pertama dan dibatasinya jumlah personel dalam kamar operasi, maka dari 1.176 kasus yang dilakukan VP shunt angka kejadian infeksinya hanya $0,17 \%$. Hal ini berhubungan dengan makin siang, sterilitas kamar operasi menjadi berkurang dan dengan banyaknya jumlah personel yang masuk kamar operasi maka makin bertambah resiko terjadinya infeksi pasca tindakan VP shunt. Makin lama operasi makin tinggi kejadian infeksi, dimana angka kejadian infeksi pasca VP shunt pada operasi <30 menit yaitu 5,2\%, sedangkan pada operasi >90 menit yaitu $13,6 \%$. Hal ini berhubungan dengan semakin lama operasi berlangsung, maka akan semakin besar kemungkinan terjadinya kontaminasi luka operasi. ${ }^{16-21}$

\section{Simpulan}

Pemberian antibiotik profilaksis sama efektifnya dengan pemberian antibiotik terapeutik pada penderita hidrosefalus kongenital yang dilakukan tindakan VP shunt. Pada penelitian ini juga didapatkan hubungan yang sangat bermakna antara faktor resiko besarnya penambahan lingkar kepala, waktu operasi, dan lamanya operasi, serta terdapat hubungan yang bermakna antara faktor risiko umur penderita dan status gizi tehadap risiko terjadinya infeksi setelah tindakan VP shunt pada hidrosefalus kongenital.

\section{Daftar Pustaka}

1. Strum LK. Neurosurgical surgical site infection: rate and prevention strategies. Int J Infect Control 2009; V5:i2.

2. Kainth K, Hunt MA, Haines SJ. The use and misuse of antibiotics in neurosurgery. In Winn HR. Youmans neurological surgery, $6^{\text {th }}$ Edition. Philadelphia: WB Saunders, 2011; p. 578-87.

3. Mangram AJ, Horan TC, Pearson ML. Guideline for prevention of surgical site infection, 1999. Hospital infection control practices advisory committee. Infect Control Hosp Epidemiol 1999;20(4):250-78.

4. Wood RK, Dellinger EP. Current guidelines for antibiotic prophylaxis of surgical wounds. Washington: American academy of family physicians; 1998.

5. Howard RJ. Surgical infection. In Brunicardi FC, Andersen DK, Billiar TR. ed. Schwartz principles of surgery, $9^{\text {th }}$ edition. New York: McGraw-Hill, 2009; p. 227-63.

6. Anderson DJ. Surgical site infections. Infect Dis Clin N Am 2011;25:135-53. 


\section{Research Article}

7. Gupta N. Shunt infections and their treatment. In Winn HR. Youmans neurological surgery, $6^{\text {th }}$ Edition. Philadelphia: WB Saunders, 2011; p. 2035-9.

8. Campbell JW. Shunt infection. In Albright AL, Pollack IF, Adelson PD. ed. Principles and practice of pediatric neurosurgery, $2^{\text {nd }}$ edition. New York: Thieme, 2008; p. 1141-7.

9. Imron A, Wiriadisastra K. Pola penyakit kongenital di bagian bedah saraf RSHS, 2003.

10. Prusseit J, Simon M, Brelie CVD, Heep A, Molitor E, Volz S, Simon A. Epidemiology, prevention and management of ventriculoperitoneal shunt infections in children. Pediatr Neurosurg. 2009;45:325-36.

11. Kulkarini A, Drake J, Pasculli ML. Cerebrospinal fluid shunt infection: a prospective study of risk factors. J neurosurg 2011;94:195-201.

12. McGirt MJ, Zaas A, Fuchs HE, George TM, Kaye K, Sexton DJ. Risk factors for pediatric ventriculoperitoneal shunt infection and predictors of infectious pathogens. CID 2003;36:858-62.

13. Lee P, DiPatri AJ. Evaluation of suspected cerebrospinal fluid shunt complication in children. Clin Ped Emerg Med. 2008;9:76-82.

14. Wang KW, Chang WN, Shih TY, Huang CR, Tsai NW, Chang CS, ect. Infection of cerebrospinal fluid shunts: causative pathogens, clinical features, and outcomes. Jpn J Infect Dis. 2004;57:44-8.

15. Duhaime AC. Evaluation and menegement of shunt infections in children with hydrocephalus. Clin Pediatr. 2006;45:705-13.

16. Park PJ, Nohra GK. Reduction of surgical-site infections in neurosurgery- the advantage of antiseptics combined with a sterile surface. Euro Neurol Rev. 2009;116-9.

17. Sciubba DM, Stuart RM, McGirt MJ, Woodwoth GF, Samdani A, Carson B, Jallo GI. Effect of antibioticimpregnated shunt catheters in decreasing the incidence of shunt infection in the treatment of hydrocephalus. J Neurosurg (Pediatrics 2) 2005;103:131-6.

18. Rehman A, Rehman T, Bashir HH, Gupta V. A simple method to reduce infection of ventriculoperitoneal shunts. J Neurosurg Pediatrics 2010;5:569-72.

19. Tulipan N, Cleves MA. Effect of an intraoperative double-gloving strategy on the incidence of cerebrospinal fluid shunt infection. J Neurosurg (1 Suppl Pediatrics) 2006;104:5-8.

20. Hayashi T, Shirane R, Yokosawa M, Kimiwada T, Tominaga T. Efficacy of intraoperative irrigation with saline for preventing shunt infection. J Neurosurg Pediatrics 2010;6:273-6.

21. Parker SL, Anderson WN, Lilienfeld S, Megerian JT, McGirt MJ. Cerebrospinal shunt infection in patients receiving antibiotic-impregnated versus strandard shunts. J Neurosurg Pediatrics 2011;8:259-65. 